\title{
Son of Per
}

\section{- Højholts personalefest: Kom som du i hvert fald ikke er!}

\author{
LARS BUKDAHL
}

\section{We Want Names}

Der er noget med Per Højholt og personer, de popper op over det hele for korte eller lange eller serielle bemærkninger, og så hedder de næsten altid noget, noget almindeligt, noget særligt almindeligt, og bemærkelsesværdigt mange gør ikke andet end at hedde noget særligt almindeligt. To digte, med tyve år imellem, er nær ved at tematisere og emblematisere denne oppoppen, det første er et lille et fra den person- og navneblomstrende Punkter (1971), det er uden titel (og jo i virkeligheden gennemsigtigt, eller rettere sagt, bogstaverne er hvide og papiret er gennemsigtigt plastic, besind jer på det):

Ligesom det ikke for nu var muligt

med begge fødder at klappe mine kinder

og sådan med hovedet mellem fødderne

på hænder at gå ud på fortovet se op

og møde den førstes blik smilende: Hej Iversen

Det er Iversen, vi er interesserede $i$, som han popper tydeligt sidelæns ud til højre i sidste linie. Og vi kan i denne anledning påstå, at det også er ham, digtet er interesseret $i$, således at hele den kontortionistiske manøvre, som beskrives i de fem lige lange linier ned til kolonnet, kun har til formål for en gang skyld at få ordentligt øje på Iversen - der NB ikke derfor behøves at have fandtes før i dette selvsamme øjeblik - og jo så Iversen som Iversen, og ikke som en Iversen: Mennesket eller Manden på gulvet eller Hin enkelte, eller hvem vil du have, fă ham på navnet helt konkret på vippen, som den dér udstikkende linie jo ligner på en prik. Vi vender i dén grad tilbage til Iversen, lige nu går vi videre til et andet digt, "Fuld stop frem", det næstsidste digt (Iversendigtet kan også gerne være det næstsidste i Punkter, hvis digtsekvens på grund af den smarte metalringhæftning er op til læseren selv) i Praksis 10: Manøvrer (I993):

Til alt groende det højst besungne: freeze nok nu! Til hvepse og făr: verweile doch! Ford Sierra Cosworth 4 X 4 Turbo: nu roligt ind til siden! Verden er vind og skæv af vores forestillinger om den! Ulf Madsen hold kæft! Du er i vejen for spurvenes tavshed og de stumme broer i det her vers: flor om vunden børn i kvinderne kors i røven! Virkeligheden er en ambulance på flugt så check din pacemaker Ulf Madsen du er på igen og det er ikke som sommerfugl!

Her er næstsidste linie en tand for lang og sidste linie en tand for kort, og så vil vi ellers bare nævne, at biler og MAD er distinkte spor, der kører delvis parallelt med navnene. Hvor Iversen ligesom manes frem, er Ulf Madsen i høj grad en forstyrrelse, fordi han så pludselig konkret i sit navn og sin bil kommer rullende ud af intet. Det forstyrrer nemlig tekstens natur- og sprogstridige forsøg på at skabe stilstand og absolut tystnad. Som ikke fuldt overbevisende varer lige præcis én linie, nemlig linie 8 , der lidt uklart skaber en forbindelse, "stumme broer", fra sorgens floromvinding over børn i kvinderne (der jo i en omvendt forstand godt kan siges at være floromvundne) til korset i røven, hvilket sidste vel simpelthen kan være stilhedens punktum i samme nu, for straks efter kører det jo afsted med virkelighe- 
den og Ulf Madsen, der jo åbenbart, som beordret, sekundkort er faldet en smule i staver, som det så smukt og sandt hedder, i hvert fald er han på igen, og han skal ikke tro, at hans absence har bragt ham $\mathrm{i}$ nogen forvandlende symbiose med naturen, så det er "ikke som sommerfugl", han er på. Hvad så som?! Ja, som Ulf Madsen vel lige præcis og hverken mere eller mindre, skabt som overfødig forstyrrelse og sendt videre på skinner og med turbo (jo mildest talt et tekstladet ord $\mathrm{i}$ forfatterskabet (en tastfejl fik mig til at opfinde ordet, forfatterskibet, for et sådant er Højholts forfatterskab virkelig, og det er flokken af autonome galejslaver, der skal portrætteres i denne artikel)).

Det er en særlig og unik ting, især $i$ tressernes og halvfjerdsernes digtning, alle disse egennavngivne personer. Det er mærkeligt nok således at lade navne befolke sine poetiske/eksperimenterende tekster, men det er helt besynderligt at befolke dem med så selvfølgeligt almindelige navne. Lad mig i første omgang bare lave en liste over alle de egennavne, og det der ligner, som optræder i Per Højholts ikke-prosaiske tekster fra og med Poetens hoved (1963), prosanavnene får sin egen lille, upræcise gruppe, for de ligner ikke uden videre (det vil (endnu) ikke $\mathrm{i}$ listen blive markeret, om der er tale om gentagne navne eller navne, der optræder $i$ klynger, ligesom der ses bort fra virkelige personers navne, navne på etablerede fiktionspersoner kan få adgang, hvis deres identitet synes fuldt overtaget og forskudt, derfor er Supermule med):

Poetens hoved: Nelly.

Min hånd 66 (I966): Hans, Pokerface Plysbjørn.

Show (1966): Hilda Petersen, Olaf Petersen, Povl, Hans, Ejvind, Louis, Oomphelia, Jack, Humphry, Oliver, Arnth, Huberstein.

Turbo (I968): henry, fru jespersen, fru andersen, fru hartman, ursula, Aage Petersen, egon.

+1 (I969): Kasper, Vibeke, Lars, Vibs, Kurt, Anders, Per, Fritz, B Schou.

Punkter: Bodil, Anders, Birte, Beate, Carl, Dorte, Erik, Frida, Grethe, Hans, Pimpernel Nielsen, Solveig, Eigil, Peter, Erna, Iversen, Sylvia, TårstrupJørgensen.
Volumen (1974): Lydia, Karin, Niels, Julius, Ejvind, Mette, Poul, Edwin, Robert, Marion, Miriam, Susan Delamel, Cathy, Mary, Ginny, Elisabeth Worre, Jenny.

Revolver (1977): Softie, Misse Thunderbolt, Inger, Ingeborg, Eddie, Otto Jensen, Verner, Fru Bech, Hans Feddersen, Rigmor Mortensen, Supermule, Cornelia.

(vi springer over Groteskens område (1978), der bare har en pyramide, der hedder Kheopteryx, og Det gentagnes musik (1989) og Lynskud (1995), for så at afslutte med den allerede nævnte)

Manøvrer: Ulf Madsen, Poul A. Nielsen, Egon.

Hans optræder i fire forskellige bøger og er dermed det absolut mest populære navn, fulgt af Poul/Povl med tre optrædener, Anders og Egon er med hver to gange, vi kan bemærke os forkærligheden for drengenavne, der begynder med ej/ey, Ejvind, Eigil, og pigenavne med et y i, Lydia, Sylvia og alle modellerne fra Volumen, Cathy, Mary, Ginny. Det slående ved navneopbuddet, bortset fra at det overhovedet finder sted, er, som man kan se, dets uhyggeligt præcise trivialitet, undtagelserne er fă, men spektakulære: bortset fra et par særsektioners farvning i Show og Volumen (modellerne), er der så også tale om en art serielle skriftsuperhelte, Pokerface Plysbjørn, Pimpernel Nielsen, Supermule og Ursulas hemmelige identitet som Pen-Ursula. Det er ikke noget tilfælde, at Hans og Poul/Povl er de populæreste navne, eller rettere det er et særdeles sigende og insisterende tilfælde, mere udspekuleret uspektakulært kan det ikke blive, og da slet ikke i avantgardistiske tryksager fra anden del af forrige århundrede. Til og med Volumen optræder almennavnene på to-tre måder, som rene oppopninger $\mathrm{i}$ klynger (som ophobninger, der rent lydligt desværre ikke rimer på oppopninger), eller singulært, i sidste tilfælde kan de godt tilstedevære halvandet øjeblik, men helst ikke længere, og som små gentagne og fortabte tekstklovner, som især i Turbo med den tålmodige Henry som hofeksemplet. Man kan iagttage en klar populationsudvikling, en kommen til verden i Min hånd 66 og Show, en egentlig befolkningseksplosion i Turbo, +1 og Punkter, og en gradvis, lettere dekadent udmatning i Volumen og Revolver. 
Det officielle farvel til almennavnene sker i de tre Revolver-tekster, der simpelthen hedder henholdsvis "Otto Jensen", "Hans Feddersen" og "Rigmor Mortensen" og er placeret ved siden af hinanden. Kun i den første tekst, en angiveligt autentisk minimal-beretning af en plejehjemspatient af samme navn (Verner er hans søn, Fru Bech en sygeplejerske), optræder navnet også i selve teksten, i de to andre signerer titelnavnet ovenfra teksterne, der er henholdsvis en straight (skrevet!) en om at svede en engel og en mere kompleks en om i sin ensomhed at drømme om børn og børnebørn i henkogningsglas (den foregår også i plejehjemsregi!), som disse særligt almindeligt navngivne personers monologer. Alle tre har faet sig et særligt almindeligt efternavn, hvilket hidtil har været undtagelsen, og de få tidligere personer, der kunne smykke sig med et sådant, måtte så som regel undvære fornavnet. Det er nærliggende at se de tre digte som almennavnenes første chance for at komme til orde, og så må det jo meget rimeligt ske i form af henholdsvis eksistentiel minimalisme, dagklar, undrende surrealisme og øm, nøgtern fordrømthed: skyggerealismer. Ulf Madsen er så en sen spøgelsesbilist (Poul A. Nielsen, præsenteres som i Revolver-trioen i titlen, og făr stillingsbetegnelsen "kontorsionist", hvilken beskæftigelses besvær han i teksten udreder, Egon II i samme bog er læseren tiltalt vistnok).

Før vi laver den prosaiske parentes, er det nok rimeligt at opliste de ovenfor udeladte historiske/mytologiske/intertekstuelle personer, som i nogle tilfælde rent faktisk agerer eller animeres i teksterne, der er især en hel del digter- og kunstnernavne næunt, og de er jo navne, og de er jo personer, utvivlsomt:

Poetens hoved: Pisarro, Cezànne, Picasso, Ikaros, Joyce, Orpheé (Orfeus), Ewald, Arendse, Eva, Malewitch, Albert Einstein.

Provinser (1964): Hemingway.

Show: Alexander Ford, James Fennimore (Cooper), Galar, Fjalar, Ordrører.

Punkter: Johannes (Ewald).

Volumen: Isolde, Robinson, Sorteper.

Revolver: Benjamin (Franklin), Jørgen Leth, Derrida, Mickey, Gud.
Groteskens område: Gud, Sophus Claussen, Brancusi.

Det gentagnes musik: Bruce Springsteen, Tododorv, Sterne, Lorca, Ewald, Blicher, Shakespeare, Kafka, Minotauros.

Manøvrer: Hendrix, Gunnar Ekelöf, Hamlet, John Coltrane, Heraklit, Cartaphilus, Hölderlin, Baggesen, Sophie (Baggesens), Gud.

Lynskud: Miles (Davis), John Lennon, Chririco, Borges, Dulle Griet, Satan, Hamlet.

I denne særgruppe kan en spejlvendt populationsudvikling iagttages. I den intenst meta-modernistiske Poetens hoved myldrer det med forfattere og kunstnere og mytologiske personer, i de med særligt almindelige personnavne spirende og svirrende værker er kändiserne så godt som fraværende (i Turbo er et par stykker synlige som deformerende puns, der er jo f.eks. legendarisk Brancusi, som bliver til en brandkusse), albuet ud, i Volumen og Revolver møder man en lille, broget grimasserende flok, i Groteskens område er de ved at finde deres værdighed igen, som repræsentanter (dvs handelsrejsende nærmest) for traditionen, for så omsider i den sene trilogi atter at indtage en fremtrædende, på samme tid frivoliseret og respekteret position, en særlig serie er de med " $\&$ " og så et digternavn betitlede og signerede ikke uden videre loyale identifikationer og hyldester. En afdemokratisering, der forslår, kunne man forledes til at mene, når man altså nøjes med at holde sig til navnestoffet i det poetiske og eksperimentelle.

Jeg har også lovet en liste over personer i prosa, og det, der ligner. Jeg har tilladt mig at placere knækprosamonologerne om Gitte i denne afdeling.

6512 (1969): Albinus, Carl, Kirsten, (Glaspisseren).

Praksis 3: Den fireogtresindstyvende frokost $i$ det grønne (1979): ( $i$ en tekst er et navn gentagne gange overstreget!)

Praksis 4: Lynmuseet og andre blindgyder (I982), Praksis 6: Salamanderen og andre blindgyder (I986), Praksis 7: Hundekunstneren og andre blindgyder (I988) (et skønsomt udvalg af de væsentligste): Hans Henrik Mattesen, Vincent Böethius, Willy Lund, Broder og Hans Adolf Brodersen, Kirsten Svensdatter, Erling Bjerregaard, Sven Holberg, Aage Hall, Georg 
Asmussen, Søren og Marie Hust, Arthur Terence Battagny, Lars Nilsøn Dable, Mr Faydon, Ada Volkersen, Tomas Edberg, Bernhard Gossen, Tavs, Kesse.

Gittes monologer (1984): Gitte, Susanne, Preben.

Praksis 8: Album, tumult (1989): Susan Pedersen.

Praksis 12: Anekdoter: C. Rørstrøm, Henriksen,

\section{B.A. Thomsen.}

Den store roman Auricula vil afslutningsvis få en selvstændig behandling. Herudover har Højholt offentliggjort kapitler fra en mindre roman, skrevet side om side om side med Auricula, Hans Henrik Mattesen. En monografi, hvis titelperson medvirker i en tidlig blindgyde.

Navnene i 6512 er behørigt pjalteproletarisk nussede, mens blindgyde-navnene er interessante og kuriøse og eksotiske, som de skal være i fantastiske fortællinger. Et par af anekdote-navnene er næsten dickensk karikerede og komiske. Gitte-trioen er i nær familie med de særligt almindelige navne, men er der ikke lige en sociologisk præciserende snert til forskel? Det efterlader os med albumtumultens Susan Pedersen, der passer på en prik i en lille tekst, som er en perfekt parallel til de navngivne tekster $i$ Revolver, især "Hans Feddersen", der jo sveder engle, Susan Pedersen făr bare øje på en lille, bebudende engel i træet uden for vinduet.

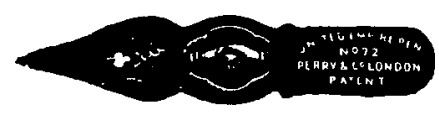

\section{It's Personal}

Navnepostyret er jo, kan det afsløres, kun et særligt tydeligt symptom på en overordnet, rigt flerstrenget strategi og praksis i Højholts forfatterskab, som vi kort kan betegne som personalisering. Hvilket til gengæld kan forståes bogstaveligt på indtil flere ledder.

For det første er selve ordet 'person' et centralt dæknavn for digter-jeg'et i en række digttitler i Revolver og den sene trilogi. I Revolver finder vi digtene, "Personen i marts, tidlig en søndag morgen" og "Personen rekonvalescent" (der frataget titlen er mottodigt for Det gentagnes musik og bagsidedigt på den samlede udgave af trilogien (1998)), i Det gen- tagnes musik digtene "Personen ved roden", "Personen i overskud", "Personen på toppen" og "Personen slår til", i Manøvrer digtene "Personen i vinden", "Personen til søs" og "Personen i ilden", I Lynskud digtene "Personen i gang", "Personen i udbrud", "Personens hyr" og "Personen ledes ved sin praksis". Der leges lidt med sådan et Kim-bog-føljeton-system i titlerne (Kim i fare, eller hvad de nu hedder), koncise smilende idiomatiske præpositionskonstruktioner, meget gerne med det spidse " $i$ ". Digtene er ikke mere ens end som så, men de er fælles om, at titelpersonen nede $i$ teksten betegnes som 'jeg' og med netop kun det formelle forbehold, netop kun den formelle forskydning og distancering, som til gengæld også er ret markant (og jo derfor også kaster skygge på de ikke personbetitlede øvrige jeg-digte i samlingerne). 'Person' kan naturligvis betyde 'son of Per', Persøn. På græsk betyder 'persona' som bekendt maske, og en vigtig tidlig digtsamling af Ezra Pund bærer netop den titel.

For det andet myldrer det i Højholts digte og tekster med personer med og uden navne, men naturligvis helst med, de agerer og de portrætteres og de taler, fylder en tekst monologisk ud fra start til slut: der er flere mere eller mindre rebusagtige rolledigte, digtet som konkret/konkretistisk nogens eller nogets taleboble. Denne generøse trafik med dens henvisninger tilbage til såvel barokke som klassiscistiske traditioner skiller sig klart ud i forhold til både modernistiske og avantgardistiske digterier i tiden (portrætter og rolledigte finder man flere steder hos især modernisterne, bl.a. Benny Andersen, Klaus Rifbjerg, Jørgen Sonne og Jess Ørnsbo, men altid som enkeltstående eller typiske tilfælde, der er aldrig den myldrende, oppoppende fornemmelse, som man får hos Højholt, det bliver aldrig på samme måde et magtfuldt og centralt spor).

Det er nu på tide at konstruere os en ny liste, nemlig over persontyper og -praksiser i Højholts poesi (i prosaen giver det $i$ højere grad sig selv, eftersom prosa jo traditionelt set uden videre opererer med indtil flere fra digterens jeg distancerede fiktive personer, et betydeligt brud på denne regel sker med Auricula, og Auricula vender vi som sagt hele ti- 
den tilbage til senere). Som det vil fremgå, undgåes overlapninger ikke.

I Digterpersoner. Personaliseringer af det traditionelle digterjeg - hvad er det, der står i Turbo: "chor af af pourlarter i højt-hellige små/ jegkoptere" - i digt eller titel, formelt simpelthen bare forvandling til 3. person. Det starter med digtet "Kirsebærskråningen" i Poetens hoved (selve titlen er måske selve halshugningen af digterjeget (titeldigtet tyer efter første linie, "Langt til havs gynger poetens hoved" lynhurtigt til jeg)), hvis første to strofer lyder således: "Træt som når hen mod sengetid et barn/ synker sammen på gulvet blandt sit legetøj/ digteren på Kirsebærskråningen// Grå og smuk i gamacher og støvfrakke/ ligner han en stor/ fra himlen nedfalden hånd i det tynde græs", hvorefter tre vældigt flotte og patetiske strofer følger inden for to gåseøjnes ramme. Allerede her forstyrrer en vis humor heroiseringen, må man sige. Det bliver værre $\mathrm{i}$ Min hånd 66, hvor digteren er blevet til en person ved navn "Poeten $\mathrm{H}$ " $\mathrm{i}$ titlen til et digt, hvis sidste linie lyder således: "og til sidst poeten $\mathrm{H}$ brugt som waterpas". Pokerface Plysbjørn i samme bog kan naturligvis også læses som en digterperson, den halvkugle han ufortrødent arbejder på er jo ifølge legenden en IBM-kuglehovedmaskine. I Turbo er en "køkkenskriver" flere gange inde over i digtets ikke urealistiske køkkenunivers som en skygge fra det opflossede digterjeg. "Person"-titlerne i Revolver og den sene trilogi er opregnet ovenfor. Interessante personhybrider er digtene "Portræt af digteren som ældre banegård" (aner man et blink til Tom Kristensens sønderskudte banegård?) fra Manøvrer og "Portræt af digteren som inkarneret katamaran" fra Lynskud, som begge med stor iver og i monologisk form forsøger at leve op til deres titler.

2 Laserpersoner. Personaliseringer og navngivning af en læser eller læseren. I Punkter optræder fem gange digte om en læser, kaldet henholdsvis "den alm læser", "laserlæseren”, "den tænksomme læser", "læseren med røntgenøjnene" og "læseren med stålbrille", han er hver gang en særdeles aktivistisk og akrobatisk herre, således udfolder sidstnævnte sig f.eks.: “jeg gentager: læseren med stålbriller folder sin tommestok sammen/ slår ud med armene og svinder gestikulerende ind bag sin brille/ mindre end et pund kaffe holder han dær sit foredrag om omega og/ kryber baglæns op i et pistolløb hvor han mumlende forpupper sig”. Som et efterskrift til digtene i Punkter tiltaler digtet "Spleen" i Manøvrer direkte sin læser i et metaforvirvar af fodbold og kosmos: "End ikke du som med spillende øjne smugdribler betydning/ vandret gennem disse linier har fætre blandt stjernerne/ du har bare set månen så tit at du tror den er din onkel/ men du tager fejl Egon du er overhovedet ikke i familie/ med universet" (lad os under dette punkt opregne de pludselige og navnløse digtpersoner, der herefter pludselig oppopper: "din skaldede onkel er højst fuldmægtig i/ Teknisk Forvaltning og dine kusiner sidder blege på stole/ og fniser over et billedlotteri”)

3 Gennemgående personer ikke til at standse ("Pokerface Plysbjørn (gennemgående figur ikke til at standse")). Digtpersoner, der via gentagne optrædender får status af en art skriftsuperhelte. Tumlingen Pokerface Plysbjørn, der fremtræder som både et stykke legetøj og en digterperson og sin helt egen vældige person, er vel den første med sin firdelte tekst i Min hånd 66, hvor han udtaler sig om sit arbejde på halvkuglen og parodisk, saboteret byder på personlige bekendelser, før han pludselig vokser sig "enorm". Så er der Henry, Ursula og Polly, der midt i Turbos virvar som måske akkurat tumlinger dukker frem op til flere gange og uden at iklæde sig nogen synderlig individualitet alligevel formår at gøre sig bemærkede: "og ursula tripper ind virrende med sit fingerbøl i øjenhøjde". I Punkter udtaler tre gange den højst almindelige pimpernel Nielsen sig under kursiverede titler (i den fjerde omgang er det fru pimpernel Nielsen, der făr ordet): “pimpernel Nielsen på vej til det offentlige toilet:/ Jeg har gjort tilnærmelser til det modsatte køn (I)/ spist en vaniljekrans (2) ført motorkøretøj (3) og/ været skeptisk (4) på Fyen (5) oppe at flyve (6) og/ medlem altid medlem af den lokale brugsforening men/ (7) æns mig næppe, sir, alt det er forbi nu! Manden/ der sælger freesia foran banken arver mit/mine spil". I Revolver optræder hele ni groteske/satiriske/frivole Supermulemonologer (Supermule er jo Fedtmules med jordnødder hemmelige og superhelteidentitet), et 
eksempel er digtet "Supermule fra luften over Chase Manhattan Bank": "SLURP! This bank is a woman! Better prevent/ than cure! Jeg lægger an til en baghyler, Mickey,/ russerne kommer, russerne kommer, hurra, hurra!/ Lige op i kassen, ja, KAFONK! og RASLE! RASLE!/ en rungende jack-pot og KLIRRE, KLIRRE! alle tiders/ saldo, ikke det dær griseri, du, ren profit, SPLAT!/ det bare ligesom at huske sine p-nødder, ik'." Endelig skal de fire tekster, to omtaler og to monologer, om pyramiden Kheopteryx i Groteskens område nævnes, den opfører sig nogen grader mere værdigt end den vilde og gale Supermule, men kolleger er og bliver de som gennemgående Højholtpersoner.

4 Digtpersoner. Blot $\mathrm{i}$ et enkelt digt centralt eller perifert agerende personer. Der er de to, der skændes kærligt "På plejehjemmet" i prosadiget med samme titel fra Provinser med samt en lille gruppe pludseligt oppoppende: "Credo" råbte han og løb nedenud af huset og hen til de tre gamle på bænken, manden med piben og den lange frakke, damen $i$ pels og barnet med den høje pande." Hypertrivielle og -konkrete er de to linier om landmåleren i "Digtet digtet digtet" i Min hånd 66, "landmålerens hat forsvinder bag bakken" og "Digtet slutter Digtet/ begynder med landmåleren og slutter med digtet". I "Frostnat" er der lige de snakkende børn, og i "så og så mange lærker" er der lige den Morris, der bliver identificeret som "postens Morris" og dermed er personudstoppet. Man kan overveje om proprietæren i den sætning i Show, der permuteres og voldtages og gøres til genstand for personlig omtale, selv ikke bare er en fredelig digtperson: "Proprietaren er $i$ haven hr i fard med at tilse sine sukkercerter". I Punkter optræder der her og dér personer, som hverken er gennemgående eller rene navneforekomster eller fræsende jeger eller tvivlsomme du'er, man kan pege på Sylvia, der dykker ind i sig selv og det tredobbelt eksponerede billede: “og her er så en gammel mand $\mathrm{m}$ solbriller/ og en pige i plasticregnfrakke med hætte/ her er manden med solbrillerne plus stok/ og plasticregnfrakken der er rød". Revolver har først og fremmest mit yndlingsdigt, "Makker" med indledningslinien "her sad han på den sten lige før og græd ned i sin øl”, men også ham der på hovedvej is bliver udsat for motorstop og den omvendte broder $i$ Thailand og så "Kongen ankommer til cafeteriaet ved havet", hvori den enigmatiske titellinie gentages stadig hyppigere og alt $i$ alt så mange gange (17), at kongen - for hvad er han også egentlig for en - er nær ved at opnå status som gennemgående person ikke til at standse; $i$ forbifarten strejfes inde på restauranten også en vis serverende "Inger nylonindpakket med skum mellem/ ørerne p-pigen som udspyer vatttamponer i toilettet". Og hvad med Lemmy, der er objekt for "Den barberede topfisse", og den frustrerede, kærligt besungne "Ingeborg i entreen" og endelig Cornelia, der ømt "bøjer sit lnæ" $i$ "Frokost $i$ det grønne"? Digtet "Er en spade" i Lynskud er et snapshot af en unavngiven, helt bestemt metaformisbrugende digter. Især i den sene trilogi myldrer det med dyr, men de personificeres med stor bestemthed netop ikke (eller hur?).

5 Personmonologer. Digte, der fremstår som fremsagt eller fremskrevet af med digteren ikke identiske personer og det, der ligner, og ikke, personificeret: Rolledigte. Flere af teksterne med gennemgående personer hører til denne type, det meste af "Pokerface Plysbjørn", Pimpernel Nielsen-digtene, Supermule-digtene, og vi nævnte tidligt digtene "Otto Jensen", "Hans Feddersen" og "Rigmor Mortensen" (der har en uhyggelig lydlig lighed med rigor mortis!) i Revolver. Trippet begynder i Poetens hoved med "Le Tombeau d'Orpheé", Orfeus' gravsten, der er sat op som et spejl og lader sig læse som samme spejls monolog sekundet før en eller anden person, "han" (= digteren?), smadrer det med en tingest, en sten givetvis "den er kastet nu stille under vejs", men lige før står jo "Le Tombeau de Joyce", der sandsynligvis er Joyces gravstens indre monolog ved Joyces begravelse i Paris: "Kastanjer i sol, huh." I digtet "Enquete" i Provinser finder man udtalelser fra både et termometer, et trykluftsbor, en vanddråbe og her en tallerken "(fald)/ Osse mig. Læg mig på en blød blød eng/ mellem de dybe, among the deep." I Revolver genoptages for alvor de eksotiske udsigelsespositioner og -personer, helst ikke uden obskøn under- og/eller overtekst, vi får monologer signeret en ulv, "Rødhætte går til sce- 
nen", en barberet topfisse ("Godaaaaaaaaaaaaaaaaaaatjih") og et lyn, "Lynet slår ned $i$ en taxa" (den nævnte Benjamin er naturligvis Benjamin Franklin og Misse Thunderbolt er simpelthen tordenen): "Lynet slår ned i en taxa; hej Benjamin, så kører vi!/ gud faaaader i skuret sikke en bryllupsnat! tænk dig hun fangede mig $i$ en bordplade og hurtigste udvej gik/ jo via bordbenet, men 65I2 ord er en seriøst handicap/ så det flækkede og nu er jeg på den: tilb tilbage til/ museet, Benjamin, gid fanden have Misse Thunderbolt!" "Poul A. Nielsen, kontorsionist" i Manøvrer, der beretter om sine knudekunster, er allerede nævnt. Næstsidst i Lynskud kæfter en lille vanskabning fra et Hieronymus Bosch-billede "Dulle Griet" op i eget navn (i et enkelt identifikatorisk \&-digt, "\& Baggesen" fra Manøvrer, bugtales der eksplicit).

6 Personportratter. Her inkluderes først og fremmest de enestående, helt fantastiske encyklopædiske, groft personificerende pseudokarakteristikker af nummererede æg og B-æg og permuterede proprietær-perioder, der udgør broderparten af Show, Højholts mest (af)guddommelige tekster. Ganske få bedragerisk selvfølgelige, men åbenlyst meningsløse, barokke, usammenhængende formuleringer og vendinger skal forestille at tegne portrætter af de umulige størrelser æg og perioder, hvilket stik imod al sund fornuft lykkes ud over al måde: Man ser dem sgu faktisk for sig. De mest tilforladelige er æggene, og lad os bare tage det allerførste, hvis nogen skulle have været så uheldige at glemme det: "Det praktiske æg er kun et barn endnu. Faderen har en radio- og fjernsynforretning i Birkerød hvor den lille ofte løber omkring, endnu ikke fortrolig med hovedsprogene. Om vinteren går tanken til de lange fygende sommerdage på de sjællandske landeveje i faderens Opel Record. Ægget er der en fremtid i, det er til at stole på og indgyder naboerne tilliden." Perioderne er lidt mere aggressivt fåmælte, f.eks. nr. "3. Proprietceren er $i$ haven frue $i$ fard med at tilse sine sukkercerter// Denne periode hedder Hans og står op hele vejen. Ekspeditionssekretær. Ses på den sydlige himmel sept.-okt. Mg-." Og når den så ovenikøbet udstyres med et så tilforladeligt navn som Hans, tror man uden videre på den ud over enhver dørtærskel.
7 Namedropping. Kendte navne og personer fra kunstens, mytologiens og historiens zoner. De er allerede blevet kommenteret ovenfor, ligesom vi under Personmonologer nævnte gravstenene for Orfeus og Joyce og \&-digtet om Baggesen. I det store digt "Nødden fra L'Estaque" i Poetens hoved taler Cezanne om sin kunst: " $\mathrm{Da}$ jeg en tidlig morgen trådte ud $\mathrm{i}$ haven/ mødte den mig $\mathrm{i}$ en uopnåelig grå" $i$ en art analytisk identifikation $i$ flere tempi. "Ansigt til ansigt til ansigt" lader $i$ al hast navnene Ewald, Arendse, Eva, Malewitch og Albert Einstein falde. Benjamin Franklin bestyrer som nævnt en taxa, der hyres af et lyn, i Revolver, hvor vi også møder digtervennen Jørgen Leth, i digtet "En lagkage til overs", som jeget rækker en lagkage videre til. I Groteksens område kunne Sophus Claussen-identifikationen "Månens gestus" sagtens have heddet " $\&$ Claussen". Af \&-digtene i den sene trilogi er " $\&$ Baggesen" som den eneste en personmonolog og "\& Blicher" fra Det gentagens musik det eneste med titelpersonen som en (naturligvis hedevandrende) digtperson, de øvrige identificerer sig mere sidelæns ind på deres ofre. En virkelig spøjs celebritypersonficering er denne lille, heftige naturiagttagelse fra Det gentagnes musik: "Nælden luder sort i middagsstunden,/ en dødsmærket bengel som kræver lyn/ med sommerfugle blafrende om hodet,/ lyn over det modne korn, torden-roer", som er blevet døbt "Bruce Springsteen" og sandsynligvis af den simple grund, at Springsteen har lavet en sang, der hedder "Thunder Road"! I den sene trilogi er der mange rene namedroppinger og et enkelt skæbnesvangert blik af Cartaphilus, den evige jøde, i sneen.

8 Navns navnelse. De pludselige enkeltstående eller myldrende oppopninger af navne (som det er fremgået ovenfor kan personer altså også godt poppe uden navns nævnelse, det tager vi ikke så tungt). Fra Turbo midt $i$ en hektisk Polly-genereret opremsning: "Polly som lighter/influenza/Aage Petersen/skoletanke/kamel". Fra Punkter, med en heldig Peter, der lige netop bliver gentaget, og her er personernes oppoppen i samme åndedrag explicit en forsvinding: "her forsvinder Solveig og hendes amme/ Eigils kørestol og Peters kufferter og/ her Peters kasket $\mathrm{m}$ fjederstål og hans/ saks og bille- 
derne af Erna i bikini." Fra den sidste forvrængede udgave af tungebrækkerremsen $\mathrm{i}+1$ : "Kasper Vibeke Lars fasters hov giv labskobs østre slip turntips pis". Også unavngiven personoppoppen kan finde sted, som der er givet flere eksempler på ovenfor, en direkte modtekst (og Højholts egen Vangede billeder) til navneoppopningen er en længere ukendt og ubetitlet fænomenal en i Volumen, der optæller personer (og udskifter dem løbende, for de er lige gode i deres helt almindelige forskellighed) $i$ et lokalsamfund, $i$ stedet for et egenavn er de navngivet med en anekdote og det, der er mindre, næsten som indianere, næsten som et ideogram, sådan som det ofte er skik, derude på landet: "ham der brækker sit ben i en ølkasse i stedet for/ ham der jager fasanerne op i stedet for/ ham der mørklægger alderdomshjemmet $\mathbf{i}$ stedet for/ ham der trækker en godsvogn til Engesvang i stedet for/ ham der bygger sommerhus af glasfiber i stedet for/ ham der græder over Karinas bryster i stedet for/ ham der vasker sig i mælk i stedet for".

Personaliseringen, kan det vel fastslåes, er en særdeles væsentlig angrebsvinkel i Højholts forfatterskab, og han udmønter den på sådan cirka samtlige de faconer, der står til rådighed, plus et par flere. Kunsten er det umuliges personalepolitik og det er fordi intetheden har ma-ma-ma-maske på, at den kan grimassere så agilt. Ser man på bøgernes sekvens, træder udviklingen meget pædagogisk frem, en attituderelativisering af det hellige digterjeg, Poeten $\mathrm{H}$, fører til flersporet og radikal personalisering, personer agerer/portrætteres $\mathrm{i}$ teksterne og tekster taler med fremmede, men altid nærmere bestemte stemmer. Det er en positiv dekonstruktion og multiplicering af den AUTORitære enstemmighed, en karnevalistisk tekstfest og så simplethen en reel, effektiv befolkning af poesien via lån fra både traditionel poesi (rolledigte/rebusdigte) og prosaen/epikken (agerende, tilstedeværende personer som sådan). En fabulerende intervention, for der er jo godt nok en hel del sære størrelser i persongalleriet, hvis min læsers laserbrille kan tåle endnu en oplistning, så kan man dele personerne op $i$ tre grupper (digterjegerne og læserjegerne holder vi uden for denne misere, og også alle de kendte): a Mytologiske/mytologiserede personer. De mere kulørte tekstsuperhelte, Pokerface Plysbjørn, Supermule, pimpernel Nielsen, kongen og ja okay så også læserne i Punkter - Turbo-personerne banker måske kraftigst på her - der i susende fart gennemflyver teksterne.

b Fabulerende/surreelle personer. De personificerede, ikke-humane sære størrelser: æg, perioder, pyramider, termometer, spejl, ulv, lyn (barberet topfisse), der tumultuøst, paradoksalt, konkret(istisk) hævder deres personlighed.

c Telefonbogspersoner. Ganske almindelige, hverdagsrealistiske personer, blot og bart ved navns nævnelse, Ejvind, eller mere udfoldet, stedt i deres realisme eller ramt af pludselige klarheder og/eller forviklinger.

Højholt insisterer i sit poetiske persongalleri således i lige mål på det trivielle og det barokke og det (pop/skrift-)mytologiske.

Det er desuden oplagt, at det er personaliseringen, der forløser mundtligheden i Højholts poesi, allerede spejlet $i$ "Le Tombeau d'Orpheé" taler ret frit fra leveren: "Men det støder mig så helt helvedes at/ han går" sammenlignet med det daværende forbillede Mallarmé. I de ikke-monologiske æg- og periode-tekster blomstrer så de umiskendelige, meningsløst afhuggede talesprogsvendinger frem: FOR MIG GERNE! Og derfra bliver det kun bedre og værre med mundtligheden, en foreløbig hypervulgær kulmination er nok Revolver (jf. Supermulecitatet).

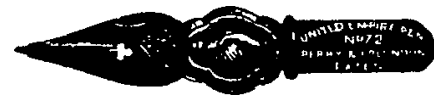

\section{I can't believe your ears}

En fyldestgørende behandling af personerne i Højholts prosa, 6512 og blindgyder, falder uden for denne artikels område eller kommer $i$ det mindste $i$ konflikt med dens ønske om overskuelighed - lad mig henvise til de mange glimrende analyser af 6512 i almindelighed og Frederik Stjernfelts behandling af blindgyderne, "Underets realisme", optrykt i $R a$ tionalitetens himmel og andre essays (1997), i særdeleshed, indtil jeg finder den rette lejlighed til at give 
mit slag på tasken - men jeg kan ikke lade være med at knytte en kommentar til Auricula. Der er to slags Højholtpersoner i romanen: syrlige namedrops: hele hoben af avantgardister i 2. bog, "Tilfældets Museum" og Marcel Duchamp i 3. bog, "Protagonisten", og en helt særlig gruppe fabulerende/surreelle personer: ørerne, som imidlertid ikke kan tale (eller høre) - til gengæld kan de i grupper "mime" - og heller ikke ejer megen individualitet, de grupper, de helst færdes i, skiller sig heller ikke meget ud fra hinanden. Den "barberede topfisse" i Revolver er som selvstændiggjort menneskeligt organ nok det tætteste vi kommer på øreagtige eksistenser blandt den fabulerende/surreelle personer (og den synes stadigvæk at have et godt tag $i$ en hel krop!), de er $i$ hvert fald fælles om en opspeedet sexualitet. Der er dog som en mareridtsfætter et sært tavst, medynksvækkende monster, som sidder og luder ved kanten af en swimmingpool i en nær-ulæselig tekst i Volumen: "Er den varm eller kold, glat eller ru, fast eller blød, en pose vand eller en muskel". Avantgardisterne og Duchamp behandles skamløst anekdotisk liv-og-værk-sammenblandende, med ørerne som privilegerede ørevidner og eneste urealistiske element, mens ørerne i deres egne kapitler behandles dels parodisk oldtidsepisk, folkevandrende i Norge og Sverige og Spanien i r. bog, "Stilheden 1915”, og dels tilbundsgående pseudo-videnskabeligt og -filosofisk, i 4. bog "Ørernes biologi og psykologi” (s. bog, "Danske ører” når lige akkurat ikke at blive den anekdotesamling om danske kendte, som den lægger op til at være). I den uhørte og oprømte samtale mellem en anekdotiseret eksperimentel tradition og en til den yderste konsekvens og ad absurdum ført fabulering, som romanen $\mathrm{i}$ et personperspektiv er, ofres først og fremmest den gamle persontrivialitet, som de oppoppende navne var de klareste signallys fra, mens mytologiseringen forskydes delvist til avantgardisterne, der alle er såre menneskelige superhelte. Digterpersonen giver sig kun til kende i stilens ødsle omhu og omstændelighed og digressivitet. Det mærkelige er, at både ørerne, som selv ikke bærer navne, og avantgardisterne, som til bevidstløshed bærer kendte navne, bliver lige så tydelige som Ejvind og Henry og Iversen, hej Iversen!

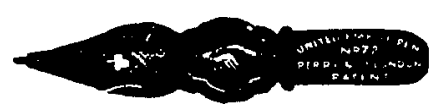

\section{Portrait of the reader as Iversen}

Hvilket jo ikke betyder, at det ikke er mærkeligt, at Iversen bliver tydelig. Dickens f.eks., der var en mester $\mathrm{i}$ at animere personer, sørgede altid for at give dem mærkelige navne, han førte hele lister over navne, de kan hedde sådan noget som Squeers eller Mrs. Gamp f.eks. Dickens' navne er umiddelbart karakterfulde, Højholts trivi-navne er diametralt modsat umiddelbart karakterløse, anonyme, og af akkurat samme grund er de lige så karaktergivende, barokt, postyrligt, ja i Punkter decideret melankolsk, fordi telefonbogseffekten er så allerhelvedes præcis. “Gale pletter" kalder Per Kirkeby et sted Dickens' personer, normale platter kunne man måske så kalde Højholts personer, i et omvendt muntert køkken, og åbne pladser - for læseren - eftersom enhver jo kan være om ikke en Henry, så en Ejvind eller en Lars eller en Erna, det er os, der kigges og hilses på med det: Hej Iversen!

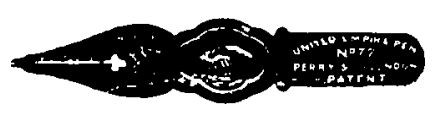




\section{Bidragydere}

LARS BUKDAHL, forfatter og kritiker

HORACE ENGDAHL, svensk forfatter og kritiker

Else-Marie Leander Fog Hansen, slavist, Københavns Universitet

Ulrich HoRst-Petersen, forfatter

KNUD MiCHELSEN, gymnasielektor, oversætter, redaktør af Versens Litteratur Leksikon, forlaget Rosinante
MinajLo PANTIC, serbisk forfatter

Peter StoterdijK, tysk filosof

Aleksander Thsma, serbisk forfatter

Poul VAD, forfatter 